\title{
NORMATIVE IR THEORY AND THE LEGALIZATION OF INTERNATIONAL POLITICS: THE DICTATES OF HUMANITY AND OF THE PUBLIC CONSCIENCE AS A VEHICLE FOR GLOBAL JUSTICE
}

\author{
PETER SUTCH
}

\begin{abstract}
This paper explores the relationship between normative international political theory and the politics of international law. It begins by arguing that a gap between the normative (in moral terms) and the moral (in legal and social terms) still exists in the literature before going on to examine an approach to closing this gap. This approach, it is argued, is common to a plurality of theoretical approaches including liberal cosmopolitanism, social constructivism and forms of particularism. In exploring 'institutional moral reasoning' or 'social moral epistemology' the paper argues that respecting the institutional autonomy of the international legal order is a key component of the approach. In order to test the extent to which the various positions do respect the autonomy of the legal order the paper engages with an analysis of the extent to which human rights have become the key constitutive norm of global politics.
\end{abstract}

Keywords: Human rights, institutional moral reasoning, international law, normative theory, social moral epistemology

The purpose of this paper is to explore how we might relate the debates concerning international justice in normative international political theory (IPT) to the debates concerning the legalization of International Relations (IR). The importance of this relationship lies in the fact that the legalization debates have opened a vital social and institutional space for the consideration of questions of international justice. Modern IR theory largely sidelined questions of justice, partly because justice was considered an institutional virtue and anarchical international politics was said to lack the relevant institutions but also because justice was a normative idea and as such fell outside the purview of a largely positivist discipline. The empirical legalization literature has

Journal of International Political Theory, 8(1-2) 2012, 1-24

DOI: 10.3366/jipt.2012.0023

(C) Edinburgh University Press 2012

www.eupjournals.com/jipt 
increasingly challenged the portrayal of IR as lacking relevant institutions and constructivist contributions to these debates have enriched our understanding of the normative context in which the constitution of the international legal order develops. Yet the gap between the legalization literature and the IPT literature that explores questions of international justice remains significant. While both explore questions of law, institution building, legitimacy and justice they do so in very different theoretical registers. Despite their common focus the literature on the legalization of international politics has tended to adopt a legal or sociological approach to normativity (here meaning the origin, legal status and impact of norms) where IPT has taken a moral approach to the normative. The legal or sociological approach offers valuable insights in to the ways that justice claims arise and how such norms function in international society. It also offers vital, institutional and normative purchase in the 'real world', a space where questions of justice can be pursued and, sometimes, acted upon. Nevertheless, from the perspective of the political theorist of international relations, such an approach offers an impoverished, rather descriptive, set of tools for dealing with the idea of justice. The moral approaches adopted in the rich IPT literature claim to remedy this but any theory of justice that fails to engage adequately with the institutional context in which normative claims are developed risks being viewed as largely irrelevant or, to use the classic IR pejorative, utopian. As the renewed interest in the justice of the international legal order intensifies the failure of normative political theory to engage with the relevant facts of the international legal order and the failure of the empirical researchers to engage with the relevant normative debates is an impediment to research. In what follows I suggest that, in order to nurture what I view as an essential synergy between the study of the sociological, the legal and the moral, we need to better understand the relation between them in order to build the necessary theoretical bridges to an understanding of the nature and potential institutionalisation of international justice.

A key reason why IR scholarship and International Law (IL) scholarship has a limited interest in questions of justice is found in the well established view of international society, and thus of international law, as a rather primitive, or immature, form of society and law. Thomas Franck, in an article entitled 'Is Justice Relevant to the International System?', argues that

the exposed role of legitimacy and the minimal role of justice distinguish the international rule system from its domestic counterparts. It is not entirely an agreeable task to argue that justice is largely irrelevant to the international rule system, but it is necessary to do so if the dynamic of that system is to be understood, studied and gradually reformed. (Franck 1989: 945)

His argument, which resonates with much of the constructivist and English School literature (see below), is that the principal agents of international society 
(states) prioritise certainty, predictability and order over justice. He argues that there is a greater incidence of voluntary compliance with rules that are perceived as emerging through legitimate process than with rules that are based on normative claims concerning justice or injustice. Justifications based on legitimacy and justice share a common structure. The extent to which a rule exerts a compliance pull depends on the strength of the shared communal standards that underpin those claims. However, "while there is considerable agreement on what makes an international rule or institution legitimate, a common measure of justice is still in its most rudimentary stage of evolution in the global community' (Franck 1989: 947). This set of ideas has significant support in the literature. Key debates in the English School centre on the relevance of order versus justice to international actors (Bull 1977; Hurrell 2007; Jackson 2003; Foot et al. 2003). Constructivists, although recently engaged with the idea of international society still appear reluctant to engage with questions of justice rather than legitimacy (Reus-Smit 2005a). Even political theorists, whose primary interest is in questions of justice, present questions of international justice as 'perplexing and underdeveloped' (Nagel 2005) and, most famously in contemporary political theory, as distinct from questions of domestic justice (Rawls 1999). Very little of this literature denies that justice is a relevant category or standard. Nevertheless the intransigence of the international system in the face of urgent claims about justice and (more often) injustice is thought to be an unfortunate but inevitable element of the study of international affairs.

Recent developments in constructivist and English School theory and in normative international political theory offer to strengthen the relationship between the theory of international society and international law on the one hand and the theories of international justice on the other. For scholars such as Andrew Hurrell, Richard Falk, Christian Reus-Smit or Terry Nardin the international rule of law has matured to the point where moral and ethical considerations have an essential, although not dominant, role on the analysis of the justice and the legitimacy of the international legal order (Hurrell 2007; Falk 1985; Reus-Smit 2004; Nardin 2000, 2008). Their work opens an important dialogue with both IR and IL scholarship. More boldly still political theorists, such as Fernando Téson or Allen Buchanan, argue the international legal order has to respond to the centrality of human rights claims which have come to be seen as the core of a justice-based account of institutional legitimacy (Téson 1998; Buchanan 2004, 2010) Nevertheless the terms of the debate are, I argue, still haunted by the theoretical barriers erected by the argument that international society is impervious to claims of justice.

The first part of this paper offers a very brief introduction to this very real gap in contemporary scholarship before looking at ways of bridging this divide. Many of the questions that need to be addressed are questions concerning the basis of the relationship between the legally normative, the sociologically normative and the morally normative. Perhaps unsurprisingly the debates in 
public international law stress the priority of the legally normative, the political scientists emphasise the importance of societal norms and the dominant voices in normative political theory assume the primacy of moral claims. The first step towards interdisciplinarity is therefore to consider the terms of engagement. In the second part of this paper I explore an account of institutional moral reasoning (or social epistemology) that, I argue, enables us to explore the idea of international justice in its relation to the legalisation of international affairs and I explore the ways in which our account of justice must be disciplined by a proper respect for the norms of international society. In section three I turn back to the law to explore the claim that humanitarian and human rights norms have evolved to the point where radical legal and political reform is called for before offering some concluding remarks on the future direction of the political theory of international law.

\section{I}

The debates in mainstream IR on the subject of the legalization of international politics were given a solid disciplinary identity in issues of International Organization in 2000 and 2001. Much of the earlier work as well as that which emerged in other journals and books after this time tends to be situated in a vibrant debate that has this oeuvre at its centre. Here, rather than restate the parameters of a well-known series of debates, I want to start with the constructivist critique of the institutionalist literature on the legalization of international politics. My purpose is to begin to explore the distance between the normative (understood in constructivist terms) and the normative (as commonly understood in moral terms). In particular I want to set the ground for considering the proper relation between three approaches to normativity. The first is the legally normative, the realm of hard or positive law. The second can be thought of as the sociologically normative, the sphere of interstitial norms (Reus-Smit 2004: 25-6; Lowe 2000: 212-19), soft law and other socially constitutive norms (political, cultural and moral norms). The third may be defined as the morally normative or the normatively desirable, a distinctive category in epistemological and ontological terms and one in which the good, the right, the just and the legitimate are explored in critical rather than descriptive terms. While these are clearly not entirely separate domains understanding the conceptual balance between these approaches to the normative is key to understanding the interface between the legal order and the idea of justice.

The constructivist responses to the liberal institutionalist accounts of the legalization of international politics are, of course, widely critical of the very narrow view of the legal presented in the liberal analysis. Martha Finnemore and Stephen Toope show that the institutionalists capture only what they term 'legal bureaucratization' and argue that legal normativity is to be found beyond 
the institutional, as narrowly defined, in the practices, traditions and beliefs of societies (Finnemore and Toope 2006: 188-205). (Where possible I have referred to the articles from the seminal legalization debates where they appear in the edited collection by Simmons and Steinberg. All subsequent references to articles will cite the date and page references of the later collection). Their 'richer view of politics and law' urges us to look beyond treaty law to customary law, to consider law as process and to take account of interstitial law - 'the implicit rules operating in and around explicit normative frameworks' (Finnemore and Toope 2006: 188). Similarly Alexander Wendt shows that 'causal depth' requires that we embed an account of the law 'within broader historical contexts that construct its elements (preferences, beliefs and so on)' (Wendt 2006: 404). Similarly, Reus-Smit's influential argument that interstitial norms are anterior to, rather than interior to, law directs our attention to the social norms that underpin the constitutional structure of international society (Reus-Smit 2003: 593). The requirement that we seek legal normativity in broader social normative enquiry is simply to acknowledge, 'part of what is going on in institutional design' (Wendt 2006: 413). But there is, as most (if not all) constructivists recognise, a third use of the term normative involved in the analysis. A focus on social norms leads us to a discussion of 'normative desirability' (Wendt 2006: 418: see also Hurrell 2007:85), to think about legitimacy and justice - the normative in the moral or ethical sense. As Finnemore and Toope point out,

Legal claims are legitimate and persuasive only if they are rooted in reasoned argument that creates analogies with past practise, demonstrates congruence with the overall systemic logic of existing law and attends to the contemporary social aspirations of the larger moral fabric of society. (Finnemore and Toope 2006: 195)

The politics of international law is intimately tied up with the debates surrounding the right, the good, the just, the legitimate. Indeed Wendt's critique of the rational design model of international law points out that all the really interesting political questions are closed to the rationalist and I want to reinforce this point about the inherently moral element of the normative debates surrounding legal normativity by quoting from Wendt's critique of positivist position on institutional legal design.

(1) Who should be the designer? In most cases states are the designers. Is this a good thing? What about those affected by international institutions? (2) What values should states pursue in their designs? Wealth? Power? Justice? (3) For whom should states pursue these values? Nations? Civilisations? Humanity? (4) What should be their time horizon? Should States care about future generations, and if so at what discount rate? (5) Should institutional designs focus on outcomes or procedure? In sum what constitutes 'the good' in a given situation to which designers should be aspiring? (Wendt 2006: 442) 
Wendt acknowledges that these questions fall outside the domain of social science and fall into the realm of normative political and international theory but he also acknowledges, as every constructivist or constitutive theory must, that such a separation is seriously problematic (Wendt 2006: 442). It is not enough to broaden the understanding of what law is and to then fight shy of engaging with that element of the normative that is shown to be an essential part of an adequate understanding of the legalization of international politics simply because it seems to be resistant to the epistemological preferences of social scientists. Without engaging with the normative in this moral sense constructivism simply replaces the rationalist error of defining international law in terms of its institutionalisation with two further problems. The first is that the normative (in the sociological sense) is defined in terms of the effects attributed to the operative norms in society. This, as Jeffrey Legro points out, is tautological and has similar failings to the rationalist model (Legro 2006: 236). Some very important (in the sense of being widely and highly valued) norms may not 'work' at all (particularly in the face of Great Power conservatism) and some norms that do 'work' may have effects that are not morally desirable. The second problem is found in defining the normatively desirable (the just, the right, the good) in terms of dominant or widely held norms even if it is possible to identify in a noncontroversial manner, such dominance. Would a universalisation of the ideals of slavery (as a matter of sociological fact) be normatively desirable? Could we even develop a critical vocabulary that allowed us to make that judgment? If we adopt such a vocabulary how do we relate it to the sociological and the legal?

It is this final set of questions that must hold our attention here precisely because they arise in the context of any sensible discussion of the legalisation of international politics. However, the way that the idea of international or global justice has been treated within normative political theory introduces problems from the other end of the equation. The dominant voice within analytic political theory has, for some time, been the neo-Kantian cosmopolitan tradition. Cosmopolitanism has been tremendously important in criticising the resistance of international theory to debates concerning justice and in uncovering the scope of injustice obscured by IR's resistance to normative or moral concerns. Nevertheless it is true to say that, even in the case of deeply politically or legally engaged scholars such as Thomas Pogge or Fernando Téson, there is a tendency to minimize (as a matter of moral theory) the relevance of the sociological or the legal. Much cosmopolitan scholarship develops an account of justice that tends to prioritise a Kantian account of practical reason over politics in a bid to keep the contingent away from the moral. My concern with such approaches is that it removes moral thinking from the context in which questions of justice arise and in which solutions are negotiated. For some cosmopolitans this concern is not relevant. For Onora O'Neill, for example, the only relevant concern is that principles of justice be formally intelligible to those for whom they are to count as principles. In a discussion of the ways that normative principles need 
to be accessible to agents O'Neill argues that genuine accessibility requires us to abstract from the particular (from the sociological or the legal) to a formal or modal understanding of the focus and scope of practical reasoning. This is, she argues, the only way to avoid idealisation - which can be loosely cast as deriving moral boundaries by favouring contingent political borders and, in the process, denying moral access to 'outsiders' (O'Neill 1996: 51; see also O'Neill 1987). For O'Neill then, a concern with the sociological and legal is a theoretical mistake. Universal moral accessibility is achieved by abstracting to practical reason rather than by finding shared normative standards. One of the more obvious problems (and one that O'Neill acknowledges) is that such a formal account of ethics is not motivationally sufficient. (O'Neill 1986: 32) nor does it consider the theoretical importance of the fact that such principles have to be institutionalised. The reluctance to engage with questions of international law or politics as a matter of theory means that O'Neill's brand of cosmopolitan theory (which I take to be an excellent example of the tradition more broadly) cannot help us connect normative IPT with legalization research. Nevertheless there are alternative accounts of accessibility found in political and international theory that have more potential.

For Andrew Hurrell 'tackling the problem of moral accessibility' means that 'arguments need to be related to the values, patterns of argument and normative structures of both international society and global society as part of a broad process of public justification and persuasion' (Hurrell 2007: 303). Importantly this point of view is not restricted to the constructivists of the English School. Buchanan's neo-Kantian cosmopolitan theory also accepts the discipline of working within the normative structures of international society. In setting up his moral theory of international law he argues that the 'requirement of moral accessibility signals that ... ideal theory's principles can be satisfied or at least seriously approximated through a process that begins with the institutions and culture we now have' (Buchanan 2004: 38).

What gets these theories off the ground is not an abstraction from the legally and sociologically normative but an active engagement with the norms of international society. Indeed normative justification is itself the product of what Buchanan refers to as 'social moral epistemology'. For Buchanan the interplay between norms and institutions is not a matter of 'mere legalization' (Buchanan 2010: 91) or merely consequentialist. Institutional reasoning is central to the justification of human rights norms. Writing in the context of an argument about human rights norms and the legitimacy of global governance institutions Buchanan argues that

the justification of claims about the existence of human rights and the legitimacy of efforts to implement human rights is not a once-and-for-all feat of abstract philosophical reasoning; it is an ongoing process in which institutionalized, public normative reasoning plays an ineliminable role. (Buchanan 2010: 5-6) 
The contention is that claims concerning global justice have developed a normative momentum within the practises of the international legal order. The normative momentum of such claims to global justice is linked to the development of community values within the international legal/political order. The key to my analysis lies in understanding the ways that each argument treats the emergence of the community values in relation to the moral fabric of international society and how they are related to a realistic assessment of the normatively desirable development of international law.

Theories that share a commitment to connecting the three senses of the normative can be said to share an interest in institutional moral reasoning or social moral epistemology. The essence of institutional moral reasoning is the claim that starting from within the discourses of international society gains the theorist of justice access to what Hurrell terms 'a stable and shared framework for moral, legal and political debate' as well as 'a stable institutional framework for the idea of a global moral community'(Hurrell 2007: 303). Allen Buchanan, writing in a very different philosophical tradition, suggests that what he terms institutional moral reasoning is an essential corrective to abstract moral theorizing on the one hand and the conservative positivism of most international law on the other (Buchanan 2004:14-70). Not only can this engaged conception of moral accessibility connect IPT with the legalization scholarship it offers us good reason to think it desirable to do so.

However, despite these theoretical sympathies, there is considerable distance between the various interpretations of the normative development of international society. The debate here is fascinating. All claim that the legalisation of international politics exhibits normative and ethical changes. At one end of the spectrum we see Nardin's recent claim that the idea of the rule of law has come to function as a non-instrumental moral constraint on state power (Nardin 2008: 385). At the other end of this continuum we find Buchanan's cosmopolitan claim that a moral theory of international law requires radical reform of the international legal order including the abolition of the state-consent model of international law (Buchanan 2004: 301-14). Between these two poles we find claims by solidarists, particularists and constitutive theorists that emphasise the cautious transition from order to justice. An example here might be Nicholas Wheeler's claim in the influential Saving Strangers that developments in the law governing the use of force show the emergence of a series of accepted mitigating arguments or legitimate exceptions to the application of the letter of the law rather than the development of new law (Wheeler 2001). The community values in question are most often cast in terms of human rights. Parallels can be drawn between the work of legal scholars such as Meron who sees, in the incremental development of a hierarchy of norms in international law, the progressive 'humanization of international law' (Meron 2006), or with Falk who heralds a 'second Grotian moment' in the development of international law (Falk 1985) and key contributions to IPT such as Buchanan's 
claim that human rights norms must be systematically applied to the legal order or Walzer's claim that the reiteration of human rights requires a rethink of the structures of international society (Walzer 2004: 171-91). The claim, common to these positions, is that the evolution of humanitarian and human rights principles (understood in the broadest normative terms) exerts (or should exert) significant pressure toward reform of the international legal order. The work that this normative evolution carries is very significant.

Famously, in Just and Unjust Wars, Walzer argues that the evolution of humanitarian and human rights norms has affected 'the moral conscience of mankind' in ways that have lead to important changes in international law, political practise and moral discourse. In Just and Unjust Wars this phrase underwrites the just use of military force-understood as preventive, pre-emptive and humanitarian warfare or the just exceptions to the non-interventionist 'legalist paradigm' (Walzer 2000: 107). In his later work it also underpins the very thin but politically urgent rights to life and liberty that begin his account of human rights (Walzer 1990, 1994). Ultimately, in the final essay of Arguing About War we find Walzer musing on the next evolution of global society on the basis of these reiterated shared ideas (Walzer 2004: 171-91). The very idea that there are acts that shock the conscience of mankind provides a sociolegal universalism which allows Walzer to make global normative and political claims (see Sutch 2009). The phrase 'the moral conscience of mankind' suits Walzer's account of reiterative moral development but it is not born of Walzer's literary style. We find the phrase embedded in public international law from the 1899 Hague Conventions and it has been an increasingly important feature of modern international law right up to the present day. In the remainder of this article I treat this evocative phrase as symbolic of the normative development of contemporary public international law. The claim, put simply, is that in the developing normative momentum of the conscience of mankind we find the evolution of communal norms that revolve around the gradual 'humanization' of international law and that this provides the normative basis for a human rights based conception of international justice. In what follows I explore the claim that we have witnessed 'the transition from an international legal system whose constitutive, legitimizing aim was peace among states (and before that merely the regulation of war among states) to one that takes the protection of human rights as one of its central goals' (Buchanan 2010: 71) in order to test the sense in which such claims take norms, in all senses, seriously in a way that vindicates their ethical prescriptions.

\section{II}

Perhaps the most celebrated instance of the phrase 'acts that shock' is in the preamble to the Universal Declaration of Human Rights. Here we learn that the 
principles therein are a response to the fact that 'disregard and contempt for human rights have resulted in barbarous acts which have outraged the conscience of mankind' (A/Res/217(III)). However the idea of a public conscience that is a universal moral compass has a much longer history (see Veuthey 2003: 198-201). In modern thought expressions of this idea, including that found in the UDHR are regarded as expressions of the 'Martens clause' which is found in the preamble to the 1899 Hague Convention with respect to laws and customs of war on land (Hague II). The clause, inserted by the Russian delegate to the conference (F. F. Martens), reads:

Until a more complete code of the laws of war is issued, the High Contracting Parties think it right to declare that in cases not included in the Regulations adopted by them, populations and belligerents remain under the protection and empire of the principles of international law, as they result from the usages established between civilized nations, from the laws of humanity, and the requirements of the public conscience. (Hague II: preamble)

While there is significant dispute (in scholarly and juridical argument) about the normative import or precise meaning of the clause it has become a permanent feature of humanitarian law, of human rights law and of public international law more generally (Meron 2000; Cassese 2000; Pustogarov 1999; Ticehurst 1997).

Despite (or perhaps because) of such widespread usage there is no agreement on the precise meaning and normative import of the Martens clause. There is, however, a clear sense that the idea of a 'humanity' capable of being shocked by the infliction of severe harm on persons plays a significant role in the development of the international legal order. This shock may lie in a reaction to vast acts of violence such as genocide or to the development of new technologies that bring indiscriminate or grotesque suffering and death (Chetail 2003: 243; Meron 2000: 84; Veuthey 2004: 613). Among the contending claims we find some very important legal interpretations of the Martens clause that underpin the political invocation of 'acts that shock'. The first is the idea that the norms associated with the clause underwrite what Meron calls 'the humanization of international law' (Meron 2006). Central to this idea is the claim that the response to 'acts that shock' has, since the UDHR, brought International Humanitarian Law (IHL) under the broad wing of International Human Rights Law (IHRL) (Meron 2000: 88; Freeman 2000; Cassese 2000: 212). This does not mean that the law of armed conflict is 'trumped' by IHRL. Rather, the progressive development of IHL is now guided by human rights standards (Chetail 2003: 241; Meron 2006: 9). This has been a vital element of the expansion of robust legal and institutional responses to crimes against humanity and war crimes. In particular it has served as the basis for the justification for humanitarian military action and the establishment of $a d$ hoc and permanent 
international criminal tribunals. A second vital claim is that the gradual legal development of 'principles of humanity and of the public conscience' (an alternate version of the Martens clause) is creating new normative hierarchies in public international law (Meron 1986; Thirlway in Evans 2003: 142; Pustogarov 1999: 134; Chetail 2003: 338). Even though there is a solid consensus on the elements of the history of 'acts that shock' (see Cassese 2003; Meron 2000; Veuthey 2003) there is dispute concerning the normative import of the Martens clause for public international law. While a complete exposition of these debates is beyond the scope of this paper it is important to get a clear sense of the contours of the principal issues in order to begin to grasp the normative potential of 'acts that shock' for international political theory.

There is broad agreement that the Martens clause has enjoyed an evolving importance in IHL and in general public international law (Cassese 200: 188; also Meron 2000: 89; Chetail 2003: 240). However, in order to get a sense of what 'acts that shock' actually means, it is important to look at the construction of the clause and its constituent parts and at the range of general interpretations that exist in the scholarly literature and in the practice of international actors. The Martens clause has taken several forms over its long life. The broad contours of 'acts that shock' are nevertheless clearly linked to the various expressions of the clause as it appears in law. I am not claiming that a positivist legal interpretation of 'acts that shock' has a monopoly on meaning (on this see Vernon 2002: 235). I do, however, think that exploring the reiterative interpretation of the clause in practice gives us a sense of the ways in which its meaning and import is socially constructed and disputed. This process is itself an examination of the social construction of knowledge, an exploration of the 'socially sanctioned' interpretation of norms (Reus-Smit 2001: 37).

When exploring the clause, legal scholars tend to treat considerations of 'humanity' and the idea of the 'public conscience' as semi-distinct elements (Meron 2000: 82-4; Pustogarov 1999: 131; Chetail 2003: 258). The idea of humanity, as expressed here, is given a narrow, but still important, construction. It is narrow in the sense that it reaffirms the principle in IHL that acts of war that are not necessary for the attainment of definite military advantage are unlawful (Kwakwa 1992: 36 in Ticehurst 1997: 129). It is important because the clause is not a simple matter of treaty law. It is significant that the clause is most often found in the preamble to key documents rather than in the main body of the text of most of the instruments that repeat it. The Martens clause is taken to be part of customary international law and is therefore of universal scope. It serves to remind all actors that there are some standards that are binding regardless of whether a state has become party to a particular treaty or has reservations against some elements of treaty law (Cassese 2000: 192). Even in the case of the Geneva Conventions, where there is no lengthy preamble and where the clause is found in the body of the text there is general agreement that the clause functions to remind parties of their obligations under customary international law (Meron 
2000: 80). The importance of this is clear as Ticehurst, quoting the International Law Commission demonstrates.

[The Martens clause]... provides that even in cases not covered by specific international agreements, civilians and combatants remain under the protection and authority of the principles of international law derived from established custom, from the principles of humanity and the dictates of public conscience. (Ticehurst 1997: 128-9; on the impact of this on case law see Meron 2000: 82-3)

The interpretation given to the 'dictates of public conscience' is even more interesting because there is some dispute over the source of 'public conscience'. For some it has its roots in opinio juris, for others it is broader and can be found in the vox populi or public opinion more generally (Meron 2000: 83). Opinio juris is an essential element of customary international law which is constituted by Usus (state practice) and the vital normative element (opinio), the belief that such action is required by international law. If the public conscience were to be determined by the (admittedly rather tricky) exploration of opinio juris it would not really add anything to existing customary international law but would demonstrate that states believe they have obligations as a result of the dictates of humanity. At the other end of the scale is the thought that public conscience reflects natural law (Ticehurst 1997: 133) and as such represents universally binding moral rules. The displacement of natural law by legal positivism has meant that contemporary public international law is quite hostile to the idea of natural law nevertheless some scholars maintain that the Marten's clause has preserved its influence. A third view here (and one that co-exists with the first interpretation) is that public opinion influences the development of international law (including customary law) "when governments are moved by public opinion to regard certain developing norms as already declaratory of customary law or as jus nascendi'. According to Meron 'this was precisely how the Rome Conference on the Establishement of an International Criminal Court formulated certain crimes in its proposed statute' (Meron 2000: 83).

The various interpretations of the elements of the Martens clause lead to similar contestations over the meaning of the clause as a whole. Most scholars follow a similar pattern to Cassese's position which divides the key claims in to three broad camps. The first is broadly interpretative and uses the clause to either establish the importance of existing customary law (to rule out the argument that whatever is not regulated by treaty is permitted) or to require that where doubts concerning the interpretation of principles of IHL arise demands of humanity and of the public conscience should inform the interpretation. The second camp is far more radical and argues that the elements of the clause establish new sources of international law - that principles of humanity and the public conscience stand beside treaty and custom as the basis of legal norms. The third argues that the clause has 'motivated and inspired' the development of IHL (Cassese 
2000: 189-90). There is real disagreement in scholarly reflection and judicial application with each interpretation finding some support in the opinions, rulings and the general interpretative pronouncements of respected jurists that stem from international courts. This disagreement concerns the extent to which 'acts that shock' establishes a moral principle at the heart of positive law.

Rather than revisit the analysis of judicial decisions found in the work of Cassese and others cited above I want to explore the sense in which the influence of 'acts that shock' has inspired international society to develop a broad consensus on a core set of community values that have a higher status than most public international law. The weight of public opinion forged in response to 'acts that shock' first yielded legal instruments designed to deal with specific acts and, gradually, led to the development of general principles capable of standing above state consent and of driving international institutional reform. Michel Veuthey shows that:

Public conscience, or perhaps it would be more accurate to say 'public revulsion', has been the driving force behind every codification of international humanitarian law over the last 150 years. Rather than the proactive inscription of lofty ideals, the major humanitarian and human rights instruments in use today are mainly the products of the painful lessons learned from the collective tragedies and humanitarian disasters of modern history. Indeed the list of humanitarian catastrophes of the late $19^{\text {th }}$ and $20^{\text {th }}$ centuries mirrors the timeline for the adoption of these instruments. (Veuthey 2003: 202)

Veuthey goes on to give just this list. Lowlights include the terrible predicament of the wounded at the battle of Solferino in 1859 (first Geneva Convention 1864), the suffering of civilians under occupation and in camps in the Second World War (1949 Geneva Conventions), the indiscriminate use of conventional weapons in Vietnam (Convention on Certain Conventional Weapons 1980), the hazard to civilian populations caused by the use of landmines (Ottawa 1997), as well as ethnic cleansing in the Former Yugoslav Republic and Rwanda (ICTY and ICTR) (Veuthey 2003: 203-4). In all of these cases a combination of lobbying by Non-Governmental Organisations and civil society groups and the work of states and international organizations can be seen to generate the response to 'acts that shock'. There appears to be a reliance on this contested and morally indeterminate idea as part of a shared process of responding to great political challenges where we lack the moral and institutional resource to cope. However, under the influence of human rights there has been a step-change in the way this process worked. As early as 1950 human rights principles were being used to flesh out the meaning of the Marten's clause (Cassese 2000: 207). Now, however, human rights principles are being used to assert the peremptory nature of norms closely associated with 'acts that shock'. Meron argues that 
under the influence of the concepts of human rights, of obligations erga omnes ... and of peremptory norms, international law has embarked on a limited transition from bilateral legal relations to a system based on community interests and objective normative relationships. (Meron 2006: 187, 256)

It is the development of this hierarchy of norms that suggests to some the subversion of the state-consent model of international law and its replacement with a hierarchy of universally binding, human rights based norms.

While the categories of norms erga omnes and jus cogens have been recognized in courts, treaties and the declaratory statements of key actors and scholars the idea that we have an uncontroversial hierarchy of norms is still hotly disputed. There is general consensus that reference to such norms has been largely (although not solely) doctrinal and rhetorical (Meron 2006: 262; also Shelton 2006). Nevertheless the way these categories respond to 'community interests' and issues of global public policy, core values such as 'basic human rights' and pressing challenges such as environmental change where international society can ill-afford to wait for consensual instruments to develop gives the political theorist interested in the development of justice rather than law in itself significant pause for thought. Obligations erga omnes were first identified by the ICJ in the Barcelona Traction case in 1970. Such obligations are owed to the international community as a whole. This means that states not harmed by the wrongful act can pursue their legitimate interest in the protection of the rights involved. Such obligations generally aim at regulating action within the borders of a state (where no other state is harmed) and so the importance of the norms themselves validates the legal interest of unaffected states (Shelton 2006: 318; Meron 2006: 259).

Similarly the category of jus cogens, recognized in article 53 of the Vienna Convention on the Law of Treaties, develops the idea that there are certain peremptory norms from which there can be no derogation. While the notion arose initially as a constraint on freedom of contract the more usual contemporary contention is that there are matters of global public policy or vital community values (often expressed in the style of the martens clause or basic human rights) that are so fundamental to the system that the law could not survive without them. There are two main ways in which this latter sense of jus cogens has been interpreted. Alexander Orakhelashvili draws the distinction between systemic and substantive norms where systemic norms are inherent in the character of the international legal order. Thus such principles would be those such as pacta sunt servanda, recognition and consent (Orakhelashvili 2006: 44-5). However, the more radical interpretation places the emphasis on the centrality of certain substantive norms such as the prohibition on the use of force, self-determination and fundamental human rights (Orakhelashvili 2006: 50-66). The crucial issue here, of course, is the extent to which international law has moved beyond a voluntarist model of legal obligation in deference to 
what Charney terms universal law (Charney 1993). The evolution of peremptory norms has led some scholars to claim that certain 'acts that shock' demand international responses that trump the desires or consent of states. Such responses, argue liberal cosmopolitans such as Buchanan, make overruling of the mechanisms of consent based international politics normatively desirable. Examples of such action include bypassing the Security Council to embark on unilateral humanitarian military action, or over-riding established interpretations of the UN Charter principles on the use of force, or establishing the universal and compulsory jurisdiction of the ICC (Buchanan 2004, 2010). Ultimately this contention brings us back to the politics of international law and the question of what we are entitled to infer from these legal and institutional developments.

\section{III}

The exposition of the Martens clause is intended to demonstrate how human rights and humanitarian concerns have gained a new importance in the international legal order. Although we appear to be witnessing a legalisation of global politics that has moved public international law in to new areas and given it new powers many commentators remain frustrated at the limits of effective action in response to humanitarian disaster and human rights abuses. The contradictory pull of much charter based law and our developing human rights culture suggests that we need reform. Institutional moral reasoning attempts to link prescriptive normative argument to the legal and social development of international society. In embedding arguments about the normative desirability of institutional reform in claims about the growing importance of human rights norms these theorists are hoping to be less reliant upon the radically disputed philosophical debates about the desirability or otherwise of human rights based reform. Yet, as I noted above, there are a wide range of positions evident in the work of theorists who adopt this approach.

The most radical argument is found in Buchanan's cosmopolitan account of legal reform demanded by a human rights based conception of justice. Underpinning all the detailed and finely crafted argument about reforming the law relating to intervention, state legitimacy, recognition and secession is the claim that human rights can, and must, be used in the place of stateconsent as the basis for legal reform (see Buchanan 2010: 71-151). His core claim is that human rights have, as a matter of legal and sociological fact, become the dominant norms of international morality. However, because they are inadequately institutionalised (primarily because our international political infrastructure stems from a pre-human rights era) we repeatedly adopt conservative or restrictionist policies on, for example, humanitarian intervention or distributive justice. It is, he argues, clear that the inability of the P5 to agree to action in Rwanda or Bosnia should be considered unjust and where 
legitimate process is perceived as enabling injustice then surely reform is desirable (Buchanan 2004: 442-3, compare with Franck above). Indeed, much of Buchanan's recent work is dedicated to showing how vast tracts of international law fail to protect or promote justice understood in terms of the highest normative commitments of the contemporary world. Buchanan is highly critical of theorists who adopt restrictionist positions without considering the normative desirability of institutional reform (Buchanan 2010: 250-79). He argues that a systematic application of the principles inherent in the international legal order will yield cosmopolitan conclusions. He goes on to argue for radical, and if necessary unilateral, reform of international institutions (including a 'coalition of rights respecting states to supplement the UNSC) (Buchanan 2004: 450-57). For many other scholars, however, this conclusion is not warranted. A crucial issue concerns the degree to which we have really have grounds to argue that human rights norms be given priority and institutionalised systematically. Importantly, Buchanan's position seems to ignore the constraints imposed by institutional moral reasoning. Institutional moral reasoning is characterised by its emphasis on social moral epistemology (above). In making his cosmopolitan argument Buchanan offers a liberal interpretation of societal norms rather than letting international society negotiate the interpretation. If this is true then Buchanan's cosmopolitanism is no more able to help IPT engage with the legalization debates than O'Neill's more abstract cosmopolitanism.

If we return to the debates surrounding the development of the Martens clause we get a sense for how key elements of international society cope with the normative impetus of 'acts that shock'. There is clear evidence to suggest that human rights norms have become increasingly important to the development of the international legal order. But the bolder claim, that human rights have become an independent source of law, does not have much credibility in legal or social terms. It is certainly not the case that the progressive development of international law leads inexorably to the cosmopolitan conclusions. We do see some striking examples of superior norms in action. The over-ruling of Rwandan reservations to the Racial Discrimination Convention and the Genocide Convention on the grounds that the rights and obligations contained in those conventions were erga omnes is a case in point (Shelton 2006: 306-7). We also see some important dissenting opinions which, while not influencing the judgment of the World Court, have an important impact on the development of law. Here the views of Judges Weeramantry and Shahabuddeen in the Nuclear Weapons Advisory Opinion that the threat or use of Nuclear Weapons could not satisfy the requirements of the Martens clause are especially important (see Meron 2000: 86; Cassese 2000: 192; Chetail 2003: 239-41; Ticehurst 1997: 126-33; Gardam 2001: 351-2). But this does not license too bold a conclusion as neither legal position ultimately triumphed over more traditional, statist principles. We also see the persistent abuse of human rights that are readily acknowledged as jus cogens such as the prohibition on torture and refoulement 
(International Commission of Jurists 2008), ongoing controversy concerning humanitarian military intervention in the UN and passivity in the face of gross human suffering. As Shelton argues:

The most significant positive aspect of this trend toward normative hierarchy is its reaffirmation of the link between law and ethics, in which law is one means to achieve the fundamental values of an international society. It remains to be determined, however, who will identify the fundamental values and by what process. (Shelton 2006: 323)

This last argument infers that we must acknowledge the process by which the developing importance of normative hierarchy is socially interpreted. Buchanan makes a strong case that existing international institutions fail to systematically apply (indeed they frustrate) their own commitment to human rights norms. But many international political theorists make this point and still fight shy of his cosmopolitanism. The evidence suggests that a great deal of care has been taken to ensure that such considerations of humanity are compatible with pluralist rather than cosmopolitan institutional structures. The scholarly consensus seems to be that we must manage the development of this element of international law to avoid 'foisting' (Shaw 2003: 115-20) these substantive and systemic changes on reluctant parties. The cosmopolitan version of institutional moral reasoning likens the increasing role of human rights norms in international society to the development of a clear hierarchy of superior norms. However, this seems to be an over ambitious interpretation and one that threatens the realization of the human rights project. As Shelton argues:

\footnotetext{
Although it may be appropriate today to recognize fundamental norms deriving from international public order, the extensive assertion of peremptory norms made by some writers and international tribunals, without presenting any evidence to support the claimed superior status of the norms under consideration, poses risks for the international legal order. (Shelton 2006: 292)
}

The incremental changes (noted above) have given us the tools to act to prevent or react to gross violations of human rights, to hold individuals criminally liable, whatever their political position and this is both to be welcomed and supported as an as yet unfinished project. However the normative risks that Shelton alludes to become clear in Meron's warning that tells us that the inflation of jus cogens norms would imperil its very existence' (Meron 2006: 396). This is not so much because the legitimacy of community values is not apparent to the moral conscience of the international community but because the institutional processes by which the ideals are developed, specified and institutionalised are not settled. The legal and political interpretation of these crucial norms does not take place in a political vacuum. As Buchanan argues 
forcefully, the relative strength of institutions to deal fairly with hegemonic influence (Buchanan calls this the parochialism objection) is crucial. Actors adopt pluralist approaches to institutional reform to create political defences against the imposition of parochial interpretations of communal norms. Where these developments threaten this pluralism we find the greatest controversy, the most objections and the general refusal to engage with the processes that might institutionalise the superiority of human rights as an independent source of law or as a matter of global public policy. It is not the case that recalcitrant states are struggling against the tide of a new account of international justice and law. In the development of erga omnes principles and crimes against humanity and, more tentatively, in the development of a substantive account of jus cogens states have recognised a human rights based account of justice that underpins legal development. However, the international community has not developed, and there is little evidence to suggest that they will ever want to develop, in a systematic way, a human rights based global public policy. The moral force of the cosmopolitan position does make this link but we should be concerned that this moves us beyond the range of institutional moral reasoning and from the moral, legal and political accessibility this grants.

If this is correct, and if the need to sustain the link between the legal, sociological and moral accounts of the normative is persuasive, then we need to turn to forms of IPT that can maintain this link. Scholars such as Hurrell, Reus-Smit and Walzer argue that the way that agents constitute the legal order, debating the merits of various interpretations of the law and of the merits of human rights driven reform, is an essential part of any social moral epistemology. One of Reus-Smit's key criticisms of the radical human rights based reforms that Buchanan draws from his analysis concerns the lack of sociological legitimacy such an order faces. In response to Buchanan's suggestion concerning the formation of a coalition of rights-respecting states who would take decisions where the UNSC could not (Buchanan and Keohane 2004: 20) Reus-Smit notes

curiously, this need for international legitimacy has been all but ignored by advocates of liberal hierarchy. They strongly imply, of course, that a democratic coalition or pacific union would be legitimate, but they attribute this legitimacy to superior political and moral qualities... By definition legitimacy is a social phenomenon, it depends on the judgment of others.... Theorists such as Fukuyama and Buchanan and Keohane might decide that democratic coalition is legitimate a priori, but if international society determines otherwise, then their judgment is moot. (Reus-Smit 2005b: 85)

Reus-Smit's account of legitimacy is close enough to Buchanan's that he too argues that human rights are a central constitutive norm in modern international politics (Reus-Smit 2001:520) and therefore understands the attractiveness of the way that Buchanan and others attempt to resolve the trade-off between 
order and justice in international society (Reus-Smit 2005b: 86). Nevertheless he believes that the liberal resolution to this key issue runs in to significant problems. What is at stake here is the account of what institutional moral reasoning requires. It requires not just that our favoured interpretation of human rights be institutionalized but that international society concurs.

Accepting the limits of institutional moral reasoning does not, however, force us into an acceptance of the status quo. It is clear that community values are developing, however tentatively, a normative momentum and it is on this basis that Hurrell gives us five reasons for expanded normative ambition and Falk demands a progressive jurisprudence. However both solidarists recognise that the idea of human rights or humanitarian based account of global justice rests on the idea of institutional moral reasoning-not just as a methodology for discovering the constitutive causes of change but as a nurturing or scaffolding device. Both recognise that international society has not transcended the pluralist model despite the range and seriousness of the problems and challenges we face and the universal moral standards we have developed to cope with them. In the structures of international society pluralism and solidarism, cosmopolitanism and statism all share a political and conceptual space (albeit uncomfortably).

So from whichever point one starts, the search for shared principles of justice will need to enquire in to the social, moral and political conditions that make for a meaningful global moral community and the degree to which they correspond to what actually exists or is likely to exist.... Global justice is not something that can be deduced from rational principles, nor can it be reflected in a single world view religious or secular; it is, rather, a negotiated product of dialogue and deliberation and therefore always subject to revision and re-evaluation. (Hurrell 2007: 43-5)

For Hurrell (and others who want to address the problem of moral accessibility through institutional moral reasoning) it is vital that political theorists in search of global justice continue to respect the institutional autonomy of international law and recognise that for all the important changes we can see the system is still pluralist, multilateralist and consent based. This does not mean that states still enjoy the old sovereign immunities of the Westphalian order. While political rhetoric, doctrine and elements of soft-law fall short of direct legal normativity all play a vital role in the development of a community of practise which Adler describes as a shared domain of knowledge, a sense of joint enterprise and mutual engagement and 'a repertoire of communal resources, such as routines, words, tools, ways of doing things, stories, symbols and discourse' (Adler 2005: 15). Examples of the power of such a community of practise can be found in the willingness of the legal order to find new custom emerging where there is far more in the way of opinio juris than state practice, in the international community's willingness to tolerate breaches of the law where humanitarian concerns necessitate it and in the increasing acknowledgment of community 
norms in political discourse. However, as Reus-Smit, Hurrell, Walzer and Adler all note we must adopt a careful approach to our interpretation if we are to remain within the bounds of institutional moral reasoning and to offer a directive account of normative desirability.

\section{IV}

If we wish to develop the link between the concern of IPT with the idea of justice and the legal and institutional norms of international society then we must respect, as a matter of theory, the idea of legal and social norms as communal resources for normative judgment. Here Adler's description of a community of practise both describes the object of our study and argues that institutional moral reasoning is necessarily communitarian. IPT owes a great debt to the early (in a sub-disciplinary sense) debates between cosmopolitanism and communitarianism (see especially Brown 1993). But those debates have left theoretical scars. Communitarianism was perceived as conservative, statist and unable to engage with 'universalist' human rights concerns. However, as Adler argues, contemporary 'analytic communitarianism' provides a synthesis between traditional cosmopolitan and communitarian approaches and between normative and analytic IR theory (Adler 2005: 4). Here communities are valued because this is where knowledge develops and evolves, and from where it diffuses, rather than being reified as the natural starting point (and end point) of enquiry. A concern with community is an essential part of Adler's social epistemology but such communities are not necessarily ethno-cultural or political units.

Communities of practise cut across state boundaries and mediate between states, individuals, and human agency on the one hand, and social structures and systems, on the other. It is within communities of practise that collective meanings emerge, discourses become established, identities are fixed, learning takes place, new political agendas arise, and the institutions and practises of global governance grow. Communities of practise are not international actors on any formal sense, but coexist and overlap with them. (Adler 2005: 15)

This form of analytic communitarianism does not imply the intellectual or political conservatism that made IPT so wary of normative communitarianism. It merely insists that IPT focus on the co-constitutive evolution of social structures as a core ontological issue. This is, of course, no small demand. It does, however, fix the study of the sociologically and legally normative as a core part of an analysis of the normatively desirable. However it also treats normative evolution as dynamic and international society as 'becoming' rather than 'being'. Unusually, perhaps, this implies that some of the most interesting theoretical resources for the analysis of contemporary claims to human rights and global 
justice are communitarian rather than cosmopolitan. For some this suggests a diminishing role for philosophy in IPT. There is, however, a rich history of IPT that sees the task of philosophy as the interpretation of ethical meaning in international society from Hegel to Rawls. Clearly there is still a debate to be had on the nature of normative IR theory that is capable of adding to the legalization debates. A lot of this work will be looking at the role of philosophical reason in relation to the norms of contemporary international society, or the relative priority of philosophy to democracy as Walzer and Rorty style it (see Walzer 1981: 379-99; Rorty 1991: 175-97; compare Buchanan 2010). Moral theory has to be capable of offering a critical perspective rather than simply aping the development of the normative fabric of international society. Nevertheless a critically relevant theory has to nurture its relationship with the legal and political even as it seeks to settle very hard cases by getting involved in an analysis of the basic (and shifting) justifications for the institutions in which such hard cases arise (see for example Frost 1996: 98). Walzer's description of IPT argues that 'the task of the moral theorist is to study the pattern as a whole searching for its deepest reasons' (Walzer 2000: 45). Studying the pattern of the legalization of world politics, and in particular the growing import of human rights norms through the prism of 'acts that shock', now offers IPT the most direct route to the analysis of international justice. Equally importantly the analytic communitarian approach found in the English School, in constructivist legalization scholarship and in the 'communitarianisms' of Adler or Walzer insists that we adopt an approach to the theory of international justice to ensures that the social construction of the normative order draws on the conscience of all mankind rather than a specific subset of them (Adler 2005: 3-5; Reus-Smit 2010: 8; Walzer 2004: 188). It is here that normative IPT finds its closest synergy with the institutional and legal debates of international affairs.

\section{References}

Adler, E. 2005. Communitarian International Relations: The Epistemic Foundations of International Relations. London: Routledge.

Brown, C. 1993. International Relations Theory: New Normative Approaches. New York: Prentice Hall.

Buchanan, A. 2004. Justice, Legitimacy and Self-Determination: Moral Foundations for International Law. Oxford: Oxford University Press.

Buchanan, A. 2010. Human Rights, Legitimacy and the Use of Force. Oxford: Oxford University Press.

Bull, H. 1977. The Anarchical Society: The Study of Order in World Politics. London: Palgrave Macmillan.

Cassese, A. 2000. 'The Martens Clause in International Law: Half a Loaf or Simply Pie in the Sky?', European Journal of International Law 11: 187-216. 
Cassese, A. 2003. International Criminal Law. Oxford: Oxford University Press.

Charney, J. 1993. 'Universal International Law', American Journal of International Law 87: 529-43.

Chetail, V. 2003. 'The Contribution of the International Court of Justice to International Humanitarian Law', International Review of the Red Cross 85: 235-69.

Falk, R. 1985. 'A New Paradigm for International Legal Studies' in Falk et al (eds), International Law: A Comparative Perspective. Boulder: Westview Press.

Finnemore, M. and Toope, S. 2006. 'Alternatives to Legalization: A Richer View of Law and Politics' International Organization (2001) 55, in Simmons and Steinberg (eds).

Foot, R., Gaddis, J. L. and Hurrell, A. 2003. Order and Justice in International Relations. Oxford: Oxford University Press.

Franck, T. 1989. 'Is Justice Relevant to the International Legal System?', Notre Dame Law Review 64: 945-63.

Freeman, M. 2000. 'International Law and Armed Conflict: Clarifying the Interplay between Human Rights and Humanitarian Protections', Journal of Humanitarian Assistance 24, http://sites.tufts.edu/jha/archives/152

Frost M. 1996. Ethics and International Relations: A Constitutive Theory. Cambridge: Cambridge University Press.

Hurrell, A. 2007. On Global Order: Power, Values and the Constitution of International Society. Cambridge: Cambridge University Press.

ICJ. 2008. Report of the Eminent Jurists Panel of the International Commission of Jurists, Assessing Damage Urging Action, http://icj.org/IMG/EJPreport.pdf.

Jackson, R. 2003. The Global Covenant: Human Conduct in a World of States. Oxford: Oxford University Press.

Koji, T. 2001. 'Emerging Hierarchy in International Human Rights and Beyond: From the Perspective of Non-Derogable Rights', European Journal of International Law 12: 917-41.

Legro, J. 2006 'Which Norms Matter? Revisiting the "Failure" of Internationalism', International Organization (1997) 51, in Simmons and Steinberg (eds).

Lowe, V. 2001. 'The Politics of Law-Making: Are the Method and Character of Norm Creation Changing?', in M. Byers (ed.), The Role of Law in International Politics. Oxford: Oxford University Press.

Meron T. 1986. 'On a Hierarchy of International Human Rights', American Journal of International Law 80(1): 1-23.

Meron, T. 2000. 'The Martens Clause, Principles of Humanity and Dictates of Public Conscience', American Journal of International Law 94: 78-89.

Meron, T. 2006. The Humanization of International Law. Leiden: Martinus Nijhoff Publishers. 
Nagel, T. 2005. 'The Problem of Global Justice', Philosophy and Public Affairs 33: 113-47.

Nardin, T. 2000. 'International Pluralism and the Rule of Law', Review of International Studies 26: 95-110.

Nardin, T. 2008. 'Theorizing the International Rule of Law', Review of International Studies 34: 385-401.

O’Neill, O. 1986. Faces of Hunger: An Essay in Poverty and Development. London: Allen Uwin.

O'Neill, O. 1996. Towards Justice and Virtue: A Constructive Account of Practical Reasoning. Cambridge: Cambridge University Press.

Orakhelashvili, A. 2006. Peremptory Norms in International Law. Oxford: Oxford University Press.

Pogge, T. 2002. World Poverty and Human Rights. Oxford: Blackwell.

Pustogarov, V. V. 1999. 'The Martens Clause in International Law', Journal of the Historv of International Law 1: 125-35.

Reus-Smit, C. 2001. 'Human Rights and the Social Construction of Sovereignty', Review of International Studies 27: 519-38.

Reus-Smit, C. 2004. 'The Politics of International Law', in Reus-Smit (ed.), The Politics of International Law. Cambridge: Cambridge University Press.

Reus-Smit, C. 2005a. 'The Constructivist Challenge after September 11', in A. Bellamy (ed.), International Society and its Critics. Oxford: Oxford University Press.

Reus-Smit, C. 2005b. 'Liberal Hierarchy and the Licence to Use Force', in D. Armstrong, T. Farrell, and B. Maiguashca (eds), Force and Legitimacy in World Politics. Cambridge: Cambridge University Press.

Rorty, R. 1991. Objectivity, Relativism and Truth: Philosophical Papers. Cambridge: Cambridge University Press.

Sen, A. 2009. The Idea of Justice. London: Allen Lane.

Simmons, B. A. and Steinberg, R. (eds). 2006. International Law and International Relations. Cambridge: Cambridge University Press.

Shaw, M. 2003. International Law. Cambridge: Cambridge University Press.

Shelton, D. 2003. 'International Law and Relative Normativity', in M. Evans (ed.), International Law. Oxford: Oxford University Press.

Shelton, D. 2006. 'Normative Hierarchy in International Law', American Journal of International Law 100: 291-323.

Sutch, P. 2009. 'International Justice and the Reform of Global Governance: A Reconsideration of Michael Walzer's International Political Theory', Review of International Studies 35: 513-30.

Prosecutor v. Duško Tadić, International Criminal Tribunal for the former Yugoslavia (2 October 1995), http://www.icty.org/x/cases/tadic/acdec/en/ 51002.htm.

Téson, F. 1998. A Philosophy of International Law. Boulder: Westview Press. 
Thirlway, H. 2003. 'The Sources of International Law', in M. Evans (ed.), International Law. Oxford: Oxford University Press.

Ticehurst, R. 1997. 'The Marten's Clause and the Laws of Armed Conflict', International Review of the Red Cross 37: 125-34.

Vernon, R. 2002. 'What is a Crime Against Humanity', Journal of Political Philosophy 10: 231-49.

Veuthey, M. 2003. 'Public Conscience in International Humanitarian Action', Refugee Survev Ouarterly 22: 198-201.

Walzer, M. 1981. 'Philosophy and Democracy', Political Theorv 9: 379-99.

Walzer, M. 2000. Just and Unjust Wars: A Moral Argument with Historical Illustrations. New York: Basic Books.

Walzer, M. 2004. Arguing About War. New Haven, CT: Yale University Press.

Wendt, A. 2006. 'Driving with the Rearview Mirror: On the Rational Science of Institutional Design', International Organization, (2001) 55, in Simmons and Steinberg (eds).

Wheeler, N. 2001. Saving Strangers: Humanitarian Intervention in International Society. Oxford: Oxford University Press. 